\title{
DERLEME
}

\section{Doğum Travmasının Anne ve Bebek Bağlanması Üzerine Etkisi}

\section{$\ddot{O Z Z}$}

\author{
Esra ALTUN $N^{1}$ Sena KAPLAN ${ }^{2}$
}

İnsan hayatında değişime neden olan en anlamlı olaylardan biri gebelik ve doğumdur. Bu değişim kadının ve erkeğin ebeveyne dönüşüm sürecidir. Doğum, kadının hayatını fiziksel, psikolojik ve sosyal yönden etkileyen çok yönlü ve önemli yaşam deneyimidir. Anne ve bebek bağlanması, gebelik döneminde gelişmeye başlayan ve sonrasında bireylerin hayatları boyunca etkisi altında kalacağı, sosyal hayattaki kişiler arası ilişkilerini etkileyen soyut bir kavramdır. Anne, baba ve bebek arasında geliştirilen olumlu bağlanmanın devamlılığı sosyal hayatın sağlıklı gelişimi için oldukça önemlidir. Bu bağlanmanın gelişmesini etkileyen birçok etken bulunmaktadır. Doğum deneyimi de insan yaşamında önemli etkilere neden olan bağlanma kavramının şekillenmesine öncülük etmektedir. Doğum deneyiminin insan üzerindeki kalıcı ve güçlü etkisi, olumlu ve olumsuz sonuçlara neden olabilmekte, özellikle travmatik doğum algısı gelişen kadınlarda anne ve bebek bağlanması olumsuz etkilenebilmektedir. Doğumun anne açısından travmatik duruma dönmesini engellemek için hemşirenin riskli grubu tanımlaması, değerlendirmesi, kadın ve ailesine destek olması oldukça önemlidir. Bu çalışmada; anne bebek bağlanması kavramına ve anne bebek bağlanmasının travmatik doğum algısı ile ilişkisini literatür bağlanımında incelemek, kadın doğum hemşiresinin sorumluluklarına dikkat çekmek hedeflenmiştir.

Anahtar Kelimeler: Anne-bebek bağlanması; Hemşirelik; Travmatik Doğum Algısı

\section{Effects of Birth Trauma on Mother-Infant Bonding Esra ALTUN $N^{1}$, Sena KAPLAN ${ }^{2}$}

\begin{abstract}
Pregnancy and birth are one of the most significant events that cause changes in human life. This change is the transformation process of men and women into parents. Birth is a multidimensional and important life experience that affects a woman's life physically, psychologically, and socially. Mother-infant bonding is an abstract concept that starts to develop during pregnancy, that influences individuals throughout their lives, and that affects interpersonal relationships in social life. The continuity of positive bonding between mother, father and the infant is very important for a healthy development of social life. There are many factors that affect the development of this bond. Birth experience also shapes the formation of the bonding concept, which has important effects on human life. The permanent and strong effect of the birth experience on humans can cause positive and negative consequences, especially in women with a perception of traumatic birth, the mother-infant bonding may be negatively affected. In order to prevent the birth from becoming a traumatic situation for the mother, it is very important for the nurse to identify the risky group, evaluate it, and support the woman and her family. This study aims to draw attention to mother-infant bonding by examining the relationship between mother-infant bonding and the perception of traumatic birth in the context of the literature, and to draw attention to the responsibilities of the obstetric nurse.
\end{abstract}

Keywords: Mother-infant bonding; Nursing; Traumatic birth perception

${ }^{1}$ Ankara Üniversitesi Tıp Fakültesi Cebeci Araştırma ve Uygulama Hastanesi Kadın Hastalıkları ve Doğum ABD, Ankara, Türkiye

${ }^{2}$ Ankara Yıldırım Beyazıt Üniversitesi Sağlık Bilimleri Fakültesi, Hemşirelik Bölümü, Ankara, Türkiye

Sorumlu Yazar: Sena KAPLAN

E-posta adresi: ataykaplan@yahoo.com ORCID No: 0000-0002-1677-5463

Gönderi Tarihi: 29.10.2020

Kabul Tarihi: 09.11.2020 


\section{GíRIŞ}

Kadının hayatındaki en önemli yaşam olaylarından biri gebelik ve doğum deneyimidir. Gebelik; hem kadın için hem de bebek için gelişimsel bir süreçtir. Kadının gebeliği süresince bebeğine bağlanması ve annelik rolünü benimsemesi oldukça önemlidir. Gebelik süresince kadının bebeğine bağlanması için fizyolojik, psikolojik, sosyolojik yönden birçok değişim meydana gelmektedir $(1,2,3)$. Gebelik sürecince yaşanan bu değişimler gebenin bebeğe karşı daha duyarlı olmasına, ona sevgi ve şefkat göstermesini sağlamaktadır (4).

Doğum, kadın ve çevresini kısa ve uzun vadede etkileyen bir yaşam olayıdır. Birçok kadın için doğum güzel hatırlanan bir deneyim iken, doğuma yönelik beklentilerin karşılanmaması doğum eyleminin olumsuz bir eylem olarak zihinde işlemesine neden olabilmektedir. Kadının doğum eylemini; kendisi ve bebeği için ölüm ya da yaralanma tehdidi olarak algılaması, travmatik doğum algısı olarak tanımlanmaktadır. Travmatik doğum algısı, kadının anne olarak kendisini yetersiz görmesine neden olmakta ve öz yeterliliğini olumsuz yönde etkilemektedir (1).
$\mathrm{Bu}$ derlemede; anne bebek bağlanması kavramına ve anne bebek bağlanmasının travmatik doğum algısı ile ilişkisini literatür bağlamında incelemek, kadın doğum hemşiresinin sorumluluklarına dikkat çekmek hedeflenmiştir.

\section{BAĞLANMA KAVRAMI}

İnsan, yaşamının sürekliliği için çevreyle etkileşim halinde olmak zorundadır. Bu etkileşimin niteliğini ise bağlanma kavramı açıklamaktadır. Bağlanma, sağlıklı duygusal-etkileşimsel ilişkiler kurabilme ve bu ilişkinin devamlılığını sürdürebilme sürecidir. Bağlanma kuramına göre; kişi kendisi için önemli olan başka bir kişi ile güçlü duygusal bağlar kurmakta ve etkileşime geçmektedir (5).

Bağlanma, intrauterin dönemde başlamakta ve hayat boyu gelişerek devam etmektedir. Gelişimsel olarak yeni doğan, ihtiyaçlarını karşılamak için yetişkine bağımlıdır. Bu nedenle bakım verecek kişiye ihtiyaç duymaktadır. Bağlanma teorisinin kuramc1s1 John Bowlby (1988), bir bebeğin birincil bakım veren figürüne/annesine arzu ettiği yakınlığı kurması ve bu yakınlığı devam ettirmesi için gösterdiği her tür davranışı bağlanma davranışı olarak tanımlamaktadır

Bağlanma davranışlarının evrimsel açıdan, 
bebeğin kendini tehlikelerden korumay hedeflediğini öne sürmektedir. Yeni doğanın duygusal ve fiziksel ihtiyaçları arttıkça bağlanmada artmaktadır $(5,6,7)$.

Doan ve Zimmerman (2003) prenatal bağlanmanın gelişimsel modelini geliştirmişlerdir. Doan ve Zimerman prenatal bağlanmayı, gebelik öncesi dönemde anne ile fetüs arasında soyut bir kavram olarak oluştuğunu, temelde de bireyin çocukluk döneminde ebeveynleriyle olan ilişkisinden etkilenerek şekillendiğini belirtmektedirler. Kadının oluşturduğu bağlanma ilişkisi, kendi annesinin bağlanma stili ile ilişkili olduğunu açıklamaktadır (8). Gebelikten önce; kadının gebelik ile ilgili duygu ve düşünceleri, gebeliği kavramsallaştırma becerileri ve doğacak olan bebeğin hayalini kurma, prenatal bağlanmanın potansiyelini oluşturduğunu savunmaktadırlar. Gebe kaldıktan sonra kadının hayatındaki durumsal değişiklikler prenatal bağlanmayı etkileyebilmektedir. Fetüsün hareketlerinin hissedilmesi, ultrason ile görüntülenmesi, kalp atışının duyulması, daha önceki gebelik deneyimleri gibi durumsal faktörler prenatal bağlanmanın şeklini belirleyebilir. $\mathrm{Bu}$ süreçte gelişen prenatal bağlanma düşük, orta veya yüksek düzeyde şekillenir. Prenatal bağlanma bilişsel, duygusal, davranışsal açılar ile sağlı uygulamaları açısından ifade edilebilir (Şekil. 1).

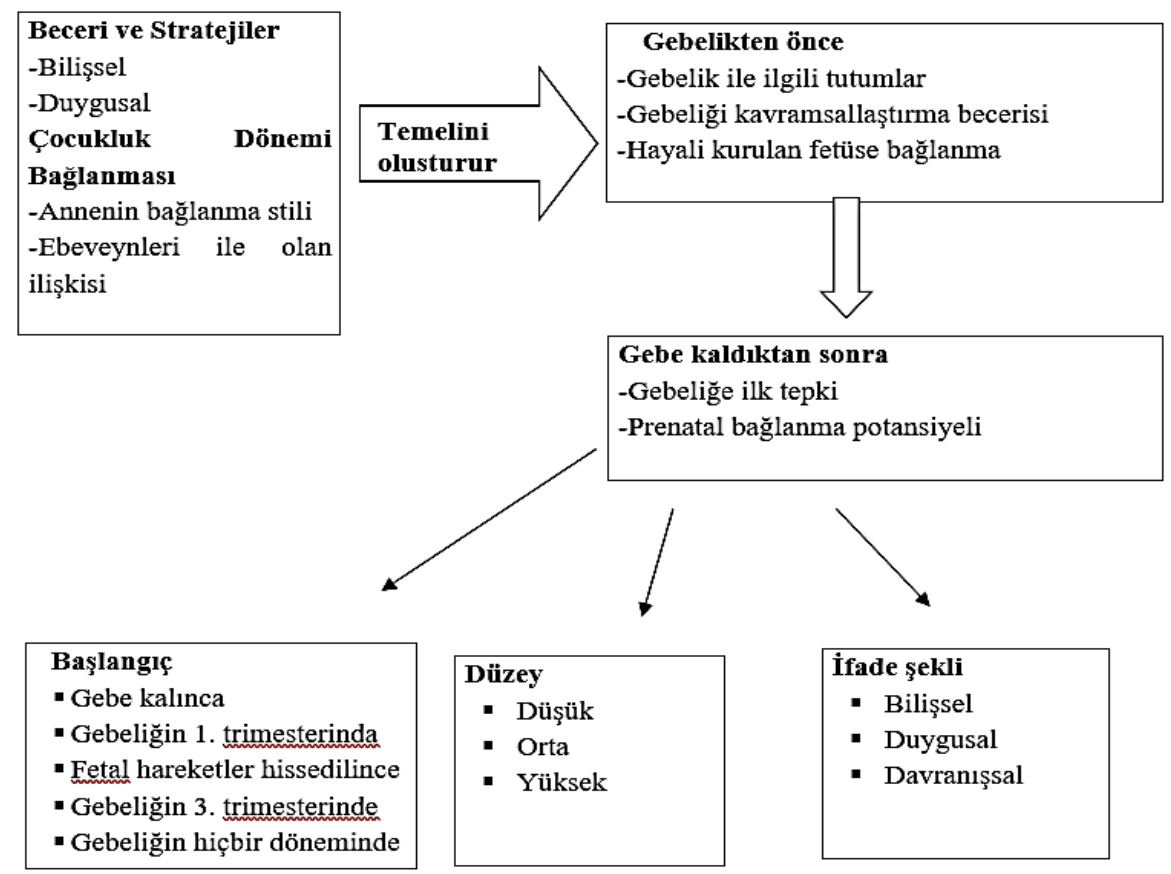

Şekil. 1: Prenatal bağlanmanın gelişimsel modeli (8) 
Prenatal dönemde bebeğin anne ve babasıly geliştirdiği sağlıklı bağlanma, bireyin hayatını etkileyen kişiler arası ilişkilerinin belirlenmesinde rol oynamaktadır. Toplum sağlığını etkileyen bağlanma sürecinin tam ve etkili gelişmesi, bebek ve ebeveyn arasındaki bağlanma ile yakından ilişkilidir $(5,9)$.

\section{Anne- Bebek Bağlanması}

Anne ve bebek arasinda kurulan ve iki tarafinda karşılıklı olarak haz duyduğu bağlanma anne ve bebek bağlanması olarak tanımlanmaktadır. Bowlby (1951) tarafindan; anne ve bebek arasında gelişen eşsiz, sürekli, yakın temasın olduğu bir kavram olarak ifade edilmektedir. Anne ile bebek arasındaki bu eşsiz ilişki, doğum öncesinde başlamakta ve doğumdan sonraki günlerde de artarak devam etmektedir (6). Gebelik haftası ilerledikçe var olan anne- bebek bağlanması artmaktadır. Anne, bebeğin fiziksel, emosyonel ve bilişsel alanda birincil ihtiyaçlarını karşılayan, primer bakımdan sorumlu olan kişidir. Bu bakım bağlılı̆̆ı, bağlanmanın oluşumunda kilit oluşturmaktadır $(2,5,6)$. Gebeliğin başlangıcından doğuma kadar fetüsün büyüme ve gelişiminin tamamlandığı, aynı zamanda annede hem fiziksel hem de duygusal değişimlerin olduğu prenatal dönem/ doğum öncesi dönem kadınların anneliğe hazırlandığ1, bağlanmanın temellerinin atıldığ1 dönemdir (10). Kadın bu dönemde bebeğini düşünmekte, hayal etmekte ve onunla etkileşime girmektedir. Anne bağlanması, ilk kez bebeğini kaybeden annelerin yaşadığı yoğun üzüntüyü araştıran Kennell tarafından öne sürülmüştür. Araştırmaya alınan kadınlar daha önce hiç görmedikleri bebeklerini görmek istemişlerdir ve yas süreci yaşamışlardır. Uzun süre birlikte yaşadıkları insanları kaybetmiş gibi tepkiler verdikleri gözlemlenmiştir $(10,11)$. Bu araştırma sonucu, anne- bebek bağlanmanın prenatal dönemde başladığını göstermektedir.

Prenatal dönemde kadınların vücutlarında meydana gelen fizyolojik ve hormonal değişimler kadınları annelik rolüne hazırlamaktadır. Karın bölgesinin büyümesi, annenin artık bebeğini hissetmesi, meme dokusunun bebek beslenmesi için gün geçtikçe gelişmesi gibi değişimler annebebek bağlanmanın gelişimi desteklemektedir. Anne adayı büyümeye başlayan bebeği için koruyucu bir tavır sergilemeye başlamaktadır. Onun gereksinimlerini karşılama endişesi 
taşımakta ve planlar yapmaya başlamaktadır.

Gebelik sürecinde başlayan bu sorumluluk içeren davranışlar, anne- bebek bağlanmanın başladığını gösteren belirtilerdir $(12,13)$.

Anne- bebek bağlanmas1; bebeğin ultrason ile görüntülenmesi, bebeğin kalp atışının duyulması, gebelik ayının ilerlemesiyle vücudun değişimi, fetal hareketlerin hissedilmesi ile kuvvetlenmektedir (14). Gebelik sürecinde anne, bebeği hem kendisine ait bir parça olarak görmekte hem de bebeğin büyüdüğünü hissettikçe ayrı bir birey olarak algılamakta, onunla duygusal bir bağ kurmaktadır. Bununla birlikte annelerde karın kısmına dokunma, bebekle konuşma, doğum öncesi ve sonrası hayal kurma davranışları görülmektedir. $\mathrm{Bu}$ bağ anne ve bebek arasında oluşacak yakın ilişkinin temelini oluşturmaktadır $(15,16)$. Gebelik sürecinde annenin koruyucu, bebeği sahiplenici içgüdüsü bebekle kurulan ilk temasla en kuvvetli halini almaktadır (16).

\section{Anne- Bebek Bağlanmasını Etkileyen Faktörler}

Anne- bebek bağlanması; bebeğin sağlıklı büyüme ve gelişmesi için zaman içinde gelişen, iki birey arasında yakınlığın temelini oluşturan önemli bir kavramdır. Anne- bebek bağlanması; annelik rolünün oluşması, anneliğe uyum, annenin bebeğine sevgi ve ilgi göstermesi, onun bütün gereksinimlerini karşılaması, güvenlik ihtiyacının giderilmesi için önemlidir. Fetüs ile sağlıklı bir bağ kuran anne, bebeğin gereksinimlerinin farkındadır. $\mathrm{Bu}$ bağın sağlıklı ve güvenli kurulmasını engelleyen birçok faktör vardır ( 17).

Annenin yaşı, doğum sayısı ve sıklığı, yaşadığ1 çevre, kültürel yap1, sosyo-ekonomik durum, eğitim düzeyi, çalışma durumu anne- bebek bağlanması üzerine etkili olmaktadır (18). Dereli ve arkadaşlarının yapmış olduğu bir çalışmada; 35 yaş üzeri gebe kalan, öğrenim düzeyi düşük olan, herhangi bir işte çalışmayan, gebeliğin planlı olmayan ve çok sayıda doğum yapmış kadınlarda anne- bebek bağlanmanın düşük olduğu belirlenmiştir (19). Yapılan diğer bir araştırmaya göre adölesan yaşta gebe kalan kadınlarda annelik kimliği geç oluştuğu görülmüştür $(17,20)$.

Yapılan çalışmalar; kadının plansız gebe kalması, annelik rolüne hazır olmayışı, bebek bakımı konusunda kendine güvenmemesi, bebeğe zarar vereceğini düşünmesi, doğum öncesi bakım alma durumu anne- bebek bağlanmasını etkilediğini göstermiştir $(1,17)$. Gebeliği planlı olan annelerin 
bağlanma düzeyleri ile diğer anneler kıyaslandığında anne- bebek bağlanmanın planlı gebeliklerde daha yüksek olduğu belirlenmiştir (18). Bunun yanı sıra anne ile bebek arasındaki bağlanma düzeyi, annenin kendi annesiyle bebeklik döneminde kurmuş olduğu bağlanma düzeyinden etkilenmektedir. Prenatal bağlanmada kadının kendi ebeveyninde deneyimlediği bağlanmanın kalitesi, oluşturacağı bağlanmanın niteliğini belirlemektedir $(17,21)$.

Anne- bebek bağlanmanın oluştuğu prenatal dönemde; kadının çevresinden ve eşinden gördüğü sosyal destek, psikolojik durumu, daha önceki gebelik öyküsü annenin ve bebeğin sağlıklı bir süreç geçirmesinde de önemli rol oynamaktadır. Corkindale' in yaptığı bir çalışmada, bağlanmanın; kadınların anksiyete durumu, eşin desteği, eş tarafından yönetilme ve eleştirilmenin etkilediği belirlenmiştir (16). Anne- bebek bağlanma, kadının ruhsal durumundan etkilenmektedir. Yapilan çalışmalar annenin var olan depresyon durumu ile bağlanma arasında ilişki olduğu göstermektedir. Ayrıca, gebelik döneminde anne ve babanın bebeğe yönelik gerçekçi hayalleri, babanında ebeveyn olmadaki heyecanı, ailesi ile olan olumlu ilişkisi anne- bebek bağlanmayı etkilemektedir $(17,21)$. Anne ve bebek bağlanmasını etkileyen faktörler arasında riskli gebelikler ve prematür doğumlarda yer almaktadır. Yeni doğanın hasta olması, erken doğması, küvezde kalma süresini etkilemekte ve anne ile olan temasının gecikmesine neden olmaktadır. Anne ve yeni doğan arasındaki ilk temasın diğer yeni doğanlara göre göreceli olarak gecikmesi bağlanmayı etkilemektedir. Yapılan çalışmalara göre; prematür bebeklerde, miadında doğan bebeklere göre iletişim ve etkileşim sürecinde daha az tepki verdikleri görülmüştür $(9,17,22)$.

Anne ve bebek bağlanmasında bebeğin sağlıklı oluşu, dış görünüşü, yüzü, hareketleri, çıkardığ1 seslerde anne ve bebek bağlanmasını etkileyen unsurlar arasındadır. Yapılan .bir araştırmada; anne ve bebek bağlanmasında bebeğin görünümün beğenilmemesi, hasta ve bedensel rahatsızlığı olan bebeklerin ebeveynleri tarafindan kabul edilmemesi, bebeğe karşı bakımın yetersiz olduğu hatta ebeveynler tarafindan bebeklerin red edildikleri görülmüştür (23). 
Anne- bebek bağlanmayı olumsuz etkileyen faktörlerden bir diğeri ise; annenin travmatik doğum algısıdır. Doğum eylemi sırasında deneyimlenecek ağrının korkusu, doğum sırasında kendine ve bebeğine zarar gelecek korkusu, doğumun gerçekleşeceği koşullar, sağlık profesyonellerinde beklenen desteğin yetersizliği travmatik doğum algısının oluşmasını tetiklemektedir. Yapılan çalışmalarda; doğum korkusu ve travmatik doğum algısının anne- bebek bağlanması olumsuz etkilediği bildirilmiştir $(23,24)$.

\section{Travmatik Doğum Algısı}

Doğum birçok kadın için çok önemli bir yaşam deneyimidir. Yapılan çalışmalara göre, kadınlar doğum eylemini "doğal, inanılmaz, fantastik, dünyaya yakınlık, dünyada çok önemli bir yaşam yolculuğu, olağanüstü bir yaşam deneyim” olarak tanımlarken (25), bazı kadınlar ise "'stres kaynağı, hayal kırıklığı, suçluluk, endişe ve korku/ acı veren bir deneyim (26)"' olarak ifade etmektedir. Doğum algısı, kadınların doğum olayındaki beklentilerini, doğum deneyimlerini ve doğum için seçtikleri yöntemleri etkileyen önemli bir algıdır. Alg1 durumunun negatif yada pozitif olarak şekillenmesinde, bireylerin kişisel, çevresel ve kültürel yapısı rol oynamaktadır (1,27). Kadının geçmişte yaşadığı çocukluk dönemi, ebeveynleri ile olan ilişki durumu, oynadığı oyunlar, kardeşin varlığı ve bakımına katılma durumu gibi birçok faktörün alg1 durumunu etkilediği bilinmektedir. Kadınlar yaşadıkları doğum deneyimlerini pozitif, negatif ya da karışı duygu durumuyla karş1layabilmektedirler. Doğum korkusunun oluşmasında; geçmişte yaşanan olumsuz doğum deneyimleri, bilgi eksikliği, karar verme mekanizmalarının kullanılamaması, medya yönlendirmeleri, sağl1k kuruluşuna yönelik eksiklikler, sağlık personellerinin davranışları, kültür ve inançlar ile aile büyükleri tarafından daha önceden yaşanmış olumsuz doğum hikayeleri rol oynadığı belirtilmektedir $(28,29)$.

Travma; bir doku ya da organın yapısını ve biçimini bozan, diştan mekanik bir tepki sonucu oluşan yara, örselenme olarak tanımlanmaktadır (30). Bu durumda bireyler için dışarıdan bir travma nedeni ve olumsuzlukla sonuçlanan bir olgu mevcuttur. Doğum travması, diğer travmalardan farklıdır. $\mathrm{Bu}$ farklılığın oluşmasının sebebi ise genellikle olumlu sonuçlanmasından 
kaynaklanmaktadır (31). Birçok kadın için doğum eylemi, olumlu beklentilerin olduğu, yaşamı değiştiren bir olaya tanıklık etmenin getirdiği duygularla karşılanırken; doğum eylemi sırasında yaşanan olumsuz olaylar sonucu travmatik bir olaya dönüşebilmektedir $(25,26)$.

Kadının doğumu, kendisi veya bebeği için yaralanma yada ölüm tehdidi olarak algılaması travmatik doğum algısı olarak tanımlanmaktadır (32). Bu algıya yol açan fiziksel ve duygusal travma durumları bulunmaktadır. Doğum eyleminde anne ve bebeğinin etkileneceği durumlar; travay sürecinde indüksiyon kullanımı, komplikasyonlu bir doğum, epizyotomi uygulaması, perine yırtıkları, kanama, fundal bası, doğum ağrısı, acil sezaryen, fetal hipoksi, doğum sırasında fetal sağlığı etkileyen anomalilerin oluşması fiziksel travmaya örnek olarak verilebilir $(31,32,34)$. Bunun yanı sıra; kadınların daha önceki doğum deneyimindeki olumsuzluklar, doğum ağrısının çok yoğun yaşanmasına bağlı kadında kontrol kaybı duygusu, doğuma ait negatif duygular, komplikasyonlu bir gebelik geçirme, gebeliğin planlanmamış olması, yetersiz antenatal bakım alma, yetersiz sosyal destek, karar verme ve yönetmede yetersizlikler, sağlık personeli tarafından yetersiz desteklenmek, bilgi ve iletişim eksiklikleri gibi nedenler duygusal travmaya yol açabilir $(33,35)$. Ayrıca, doğum korkusu kadının, doğumda öz yeterlilik beklentilerini olumsuz etkilemektedir. Kadın doğum sırasında kontrol kaybı yaşamakta ve doğumda sunulan desteği yetersiz görerek doğumun travmatik olarak algilanmasina neden olabilmektedir (36).

Doğum eylemi birçok kadın için pozitif bir yaşam deneyimidir. Beklenenin aksine travmatik bir doğum deneyimi yaşayan kadının doğuma ait duyguları olumsuz etkilemekte, ileriye yönelik beklentilerini karşılamada yetersiz kalmaktadır. Kadınların doğum ile ilgili beklentileri kişisel, çevresel faktörlerle şekil almaktadır. Bu beklentiler olumsuz olarak oluşmuşsa daha sonraki doğumlar dehşet verici hale dönüşebilir (37). Daha önceki travmatik doğum deneyimi ve süreğen doğum süreci ilişkilendirildiğinde doğum tercihlerinin sezaryen ile şekillendiği görülmektedir. Travmatik doğum deneyimi sonrası doğum korkusu yaşayan kadınlarda sezaryen ile doğum 5,2 kat arttığ görülmektedir. Çakmak ve arkadaşlarının yaptığı çalışmada isteğe bağlı sezaryen doğumu tercih 
edeceğini ifade eden kadınların tercih nedenleri şöyledir: \%42,2 vajinal doğumdan korkma, \%31,6 sezaryenin ağrısız olması \%15,8 sezaryende anne ve bebeğin daha az zarar görmesi ve $\% 10,5$ vajinal doğumun daha riskli olduğunu düşünmedir $(38,39)$.

Travmatik doğum deneyimleyen kadınlarda; suçluluk duygusu, doğumu s1k sık hatırlama, korku ve panik atak durumları, bebeği ve eşini red etme gibi durumlarla karşı karşıya gelmenin yanı sıra anne- bebek bağlanmanın yetersiz ve güvensiz gelişmesine neden olduğu bilinmektedir. Kadının yaşamış olduğu travmatik doğum deneyimi, bir daha gebe kalmayı istememe, kürtaj olma, aile içi ilişskilerde çatışma, gebelikten korunmak için cinsel yaşamdan kaçınma, doğum tercihlerinin değişmesine neden olabilmektedir $(32,40)$.

Travmatik doğumun olumsuz diğer bir sonucu ise kadın ve erkeğin ailevi ilişkilerinin etkilenmesidir. Kadın eşinden yeterinde ilgi görmediğini düşünmektedir. Aynı şekilde olumsuz düşüncelere sahip olan kadın tarafından erkek de ihmal edildiğini düşünmektedir. Çevresinden ve eşinden yetersiz ilgi gördüğünü düşünür. Bununla beraber olumsuz aile ilişkileri sonucu cinsel isteksizlik, boşanmalar görülebilmektedir. Bu durum ileriki dönemde kişi, aile ve toplum sağlığı için risk oluşturmaktadır (31).

Doğum sonu dönemde de travmatik doğumun oluşturduğu yıkıcı etkiler devam etmektedir. Annenin psikolojik dengesinin bozulmasina ve çevre ile uyumunda dengesizliklerin oluşmasına neden olmaktadır. Doğumu travmatik olan algilayan kadınlarda post-travmatik stres bozukluğu, post-partum depresyon görülme sıklığ artmaktadır $(41,42)$. Olumsuz bir doğum deneyimi, gebenin kendini yetersiz görmesine, daha sonraki doğumlarında da doğum korkusuna neden olmaktadır. Türkiye'de '’Travmatik Doğum Algısı Ölçeği”, ile yapılan bir çalışmada, kadınların \%26.9'unun yüksek düzeyde travmatik doğum alg1sı yaşadığı belirlenmiştir (43). Diğer bir çalışma; travmatik doğum deneyimi geçiren kadınlarda Post-travmatik Stres Sendromu gelişme oranın \%3.1- \%15.7 arasında olduğunu belirtmektedir (44).

Travmatik Doğum Algısı Gelişen Kadınlarda Anne- Bebek Bağlanması ve Hemşirelik Yaklaşımları

Doğum eylemi süreci multidisipliner bakım gerektiren bir süreçtir. Kadın hastalıkları ve doğum 
uzmanları, ebe, hemşire, psikolog, sosyal hizmet uzmanlarının bir arada uyum içinde çalışması gereken bir süreçtir. Doğum eylemi süreci içinde ekip içerisinde sağlık profesyonellerinin, kadına ve eşlerine yardımcı olabilmesi için öncelikle kendilerine ait doğum ile ilgili olumsuz düşüncelerini değiştirmesi gerekmektedir. Ekip içerisindeki bütün personelin özellikle hemşirelerin kadına yönelik var olan risk faktörlerini belirlemesi, değerlendirmesi ve gerekli önlemlerin alınmasında rol ve sorumlulukları bulunmaktadır $(31,43)$.

Hemşireler ve ebeler tarafından, sağlıklı ve planlı gebeliklerin oluşması için; birinci basamak koruyucu aile planlaması hizmetlerinin sunulması, bilgi eksikliğinin eğitimlerle giderilmesi gerekmektedir. Doğum öncesi, doğum anı ve doğum sonu dönemde kadınların düzenli ve sürekli takibinin yapılması önem taşımaktadır. Kadının daha önceki doğum deneyimi, şuan ki gebelikten beklentisi, doğum ile ilgili her alanda bilgi ihtiyacının belirlenmesi ve giderilmesi, gerekirse destek birimlere yönlendirilmelerin yapılması, ebe ve hemşirelerin sorumlulukları arasında bulunmaktadır $(45,46)$.
Toplumsal baskının yüksek olduğu bölgelerde kadınlar kendilerini yeterince ifade edememektedir. Oluşan olumsuz etkilerin fark edilememesi ve tedavi edilememesi birçok kadında ve ailelerinde geri dönüşü olmayan durumlara yol açmaktadır $\quad(31,47) . \quad$ Sağlık profesyonelleri tarafından bulunulan toplum ve kültür göz ard1 edilmemeli, kadın çevresiyle bir bütün olarak değerlendirilmelidir. Doğum eylemi sürecinde hemşirenin kadını aydınlatıcı bilgi vermesi, desteklemesi, var olan endișelerinin giderilmesi son derece önemlidir. Kadında geçmişte olumsuz yaşamış olduğu bir doğum eylemi öyküsü varsa kadının şuandaki süreçte de anksiyete ve korku düzeyi yüksek olabilmektedir. Hemşire kadının kendini ifade etmesini desteklemeli, destek alanlarını belirlemeli ve gerekli ortamı oluşturmalıdır. Bu durumlarda kadınlara doğum ve doğum sonrası dönemde travmatik doğum algısına karşı baş etme yöntemleri sunulması önem taşımaktadır $(45,46)$.

Anne ve bebek etkileşimi, sağlık profesyonelleri tarafindan doğum sonrası en erken dönemde sağlanmalı ve emzirme konusunda destek olunmalıdır. İlk temas anne- bebek bağlanmasının 
güvenli oluşmasında en önemli etkenler arasındadır. Aynı zamanda eş desteği sağlanması son derece önemlidir (41). Annenin kendini ifade etmesi konusunda cesaretlendirilmeli ve tercih ettiği yakınının yanında olması sağlanmalıdır. Gerekirse profesyonel destek alması sağlanmalıdır. Travmatik doğum deneyimleyen kadınların benzer deneyim yaşayan diğer kadınlarla etkileşim kurması ve destek grupları oluşturulması sağlanmalıdır. Gerekli bakım ve destek sağlanarak annelik rolüne uyum desteklenmelidir (47).

Doğum sonrası postravmatik stres bozukluğu açısından risk değerlendirilmesinin yapılması, belirlenmesi ve danışmanlık hizmetinin sunulması önemlidir. Taburculuk sonrası postravmatik stres bozukluğu açısından risk oluşturabilecek kadınların doğum sonrası ev ziyaretleri ile izlenmesinin devam etmesi, gerekirse profesyonel destek alması sağlanmalıdır. Bunun yanı sıra, doğum sonu izlemlerde babaların da depresyon açısından değerlendirilmesi ve taramalara dahil edilmesi önem taşımaktadır $(41,47,48)$.

\section{SONUÇ VE ÖNERILLER}

Sonuç olarak doğum birçok kadın için olumlu bir deneyim olarak karşılanırken bazı kadınlar için travmatik olarak algılanmaktadır. Travmatik doğum algısının hem kadının hem de bebeğinin sağlığını olumsuz etkilemesi nedeniyle annebebek bağlanmasının erken dönemde başlatılması ve devamlılığının sağlanması oluşabilecek olumsuzlukların engellenmesi için çok önemlidir. $\mathrm{Bu}$ nedenle doğum travmasının gelişmeden önlenmesinde, tanılanmasında ve var olan durumu tedavi etme sürecinde ekip çalışması çok önemlidir. Yaşamın bir parçası olan doğum eyleminin sağlıklı olması ve travmatik bir eyleme dönüşmemesi için kadın sağll $\breve{g ̆}_{1}$ hemşirelerine büyük görevler düşmektedir. Birincil amaç doğum travmasının oluşmasının önlenmesi, oluşmuş ise erken dönemde tespiti ve doğum sonu sunulan kaliteli bakım ile olumlu algıya dönüşmesinin sağlanmasıdır. Doğum sonu servislerinde çalışan hemşirelerin anne- bebek arasında pozitif bă̆ kurulmasını sağlamak için aşağıdaki önerilerden yararlanabilirler.

- Doğum sonu servislerinde çalışan hemşirelerin kadını, ailesi ile birlikte bütüncül olarak ele alması önemlidir. Ebeveynlerin stres faktörleri belirlenmeli ve ilgili birimler hakkında bilgi verilmeli, iletişime geçmesi desteklenmelidir. 
- Doğum sonrası taburculuk öncesinde anne ile görüşülerek doğum algısı değerlendirilmelidir.

- Ebeveynlerin bebek ile etkileşimlerinin huzurlu, güvenilir olması için ortam oluşturulmalı, anne ve babanın bebek ile ten tene teması sağlanmalı, bebek ile iletişime geçmeleri desteklenmelidir.

- Anne ve babanın ebeveyn olarak var olan endişeleri belirlenmeli, kendilerini ifade etmeleri desteklenmelidir. Ebeveynlerin hayalini kurdukları bebekleri ile yeni doğan arasında zihinsel özleştirme desteklenmeli, bebeğin gereksinimlerine yönelik bilgilendirme sağlanarak farkındalık oluşturulmalıdır.

- Hemşirelerin ebeveyn ile bebek arasındaki etkileşimini izlemesi önemlidir. $\mathrm{Bu}$ aşamada doğum sonu depresyonun erken tanılanması ve gerekli destek koşullarının sağlanması gerekmektedir.

- Ailelerin istedikleri zamanda istedikleri sayıda çocuk sahibi olmaları için taburculuk sırasında aile planlaması yöntemleri anlatılmalıdır. Ebeveynlere doğum sonu kontrollerin önemi anlatılmalı ve kontrollere düzenli gelmeleri konusunda bilinçlendirilmelidir.

- Ebeveynlerin sosyal, çevresel ya da finansal sıkıntılarına yönelik ilgili kurum ve kuruluşlar hakkında bilgi verilmesi, yönlendirilmesi ve desteklenmesi sağlanmalıdır.

- Taburculuk eğitimi sırasında ebeveyn ile bebek bağlanmasının öneminden bahsedilmelidir. Anne- baba- bebek arasında oluşturulmuş güvenli bağlanma olumlu aile ilişkisi için çok önemlidir.

\section{KAYNAKÇA}

1. Aslan Ş, Okumuş F. Primipar kadınların doğum deneyim algıları üzerine doğum beklentilerinin etkisi. Journal of health Science and Profession - HSP. 2017; 4(1): 32-40.

2. Topaç Tunçel N, Kahyaoğlu Süt H. Gebelikte yașanan anksiyete, depresyon ve prenatal distres düzeyinin doğum öncesi bebeğe bağlanmaya etkisi. Jinekoloji -Obstetrik ve Neonatoloji Tıp Dergisi. 2019;16(1): 9-17.

3. Bolsoy N, Çelik N, Şimşek HN. Doğum korkusu yaşayan kadınlarda psiko-eğitim obstetrik ve maternal sonuçları iyilestirir mi? Sistematik inceleme. Dokuz Eylül Üniversitesi Hemşirelik Fakültesi Elektronik Dergisi. 2019; 12(1): 82-90.

4. Bilgin Z, Alpar E. Kadınların maternal bağlanma algısı ve anneliğe ilişkin görüşleri. Sağlık Bilimleri ve Meslekleri Dergisi .2018; 5(1): 6-15.

5. Güleç D, Kavlak O. The study of reliability and validity of paternal-infant attachment scale in Turkish society. Journal of Human Sciences. 2013; 10(2): 170-181.

6. Bowlby J (1988) A Secure Base: Clinical Applications of Attachment Theory. London, Routledge.

7. Aydemir H K, Alparslan Ö. Anne- bebek bağlanma ölçeğinin Türk toplumuna uyarlanması: Aydın örneği. J.Contemp Med. 2016; 6(3): 188- 199.

8. Golbasi Z, Ucar T, Tugut N. Validity and reliability of the turkish version of the maternal antenatal attachment scale. Japan J Nurs Sci. 2015; 12(2): 154-161.

9. Kavlak O, Şirin A. Maternal Bağlanma Ölçeği’nin Türk toplumuna uyarlanması. Uluslararası İnsan Bilimleri Dergisi. 2009; 6(1): 188-202.

10. Kennell J.H, Slyter H, Klaus M.H. The mourning response of parents to death of a newborn infant. The New England Journal of Medicine. 1970; 283(7): 344-349.

11. Koopmans L, Wilson T, Cacciatore J, Flenday V. Support for others, fathers and families after perinatal death. Cochrane Database of Systematic Reviews. 2013; 19(6): 1-22.

12. Alan $\mathrm{DH}$, Çankaya S. Maternal obezitenin prenatal bağlanma üzerine etkisi. Artvin Çoruh Üniversitesi Sağlık Bilimler Dergisi. 2018; 9(2): 118-123.

13. Nishikawa M, Sakakibara H. Effect of nursing intervention program using abdominal palpation of leopolds maneuvers on 
maternal-fetal attachment. Reproductive Health. 2013; 10(12): 17.

14. Mutlu C, Yorbik O, Tanju I, Çelikel F, Sezer R. Doğum öncesi, doğum sırası ve doğum sonrası etkenlerin annenin bağlanması ile ilişkisi. Anatol. J. Psychiatry. 2015; 16(6): 440-450.

15. Akarsu Höbek R, Tuncay B, Alsaç Yüzer S. Anne-bebek bağlanmasında kanıta dayalı uygulamalar. Gümüşhane Üniversitesi Sağlık Bilimleri Dergisi. 2017; 6(4): 275- 279.

16. Yılmaz SD. ' Prenatal anne- bebek bağlanması'. Hemşirelikte Eğitim ve Araştırma Dergisi. 2013; 10(3): 28-33.

17. Nacar Hoca E, Gökkaya F. Bağlanma ve maternal bağlanma konusunda bir derleme. Kıbris Türk Psikiyatri ve Psikoloji Dergisi. 2019; 1(1): 50-56.

18. Çoban A. (2003). Doğum sonrası anne- yeni doğan etkileşimini etkileyen bazı etmenlerin incelenmesi. (Yayınlanmamış Yüksek Lisans Tezi) Ege Üniversitesi, Sağlık bilimleri Enstitüsü.

19. Dereli Yılmaz S, Kızılkaya Beji N. Gebelerin stresle başa çıkma ve depresyon düzeyleri. Genel Tıp Dergisi. 2010; 20(3): 99-108.

20. Elkin N. Gebelerin prenatal bağlanma düzeyleri ve bunları etkileyen faktörler. Sürekli Tıp Eğitimi Dergisi. 2015; 24(6): 230236.

21. Koptur A, Emül Güler T. Fetüs ve yenidoğanda bağlanmanın iki yüzü: maternal ve paternal bağlanma ve hemşirelik. Ege Üniversitesi Hemşirelik Fakültesi Dergisi. 2017; 33(3): 153-164.

22. Güleşen A, Yıldız D. Erken postpartum dönemde anne bebek bağlanmasının kanıta dayalı uygulamalar ile incelenmesi. TAF Prev Med Bull. 2013; 12(2): 177-182.

23. Şolt A, Savaşer S, Dolgun G. Doğum sayısının anne bebek bağlanmasına etkisi. Sağlık Bilimleri ve Meslekleri Dergisi. 2017; 4(3): 236-243.

24. Hergüner S, Çiçek S, Annagür A, Örs R. Doğum şeklinin doğum sonrası depresyon, algılanan sosyal destek ve maternal bağlanma ile ilişkisi. Düșünen Adam The Journal of Psychiatry and Neurological Sciences. 2014; 27(1): 15-20.

25. Karström A, Nystedt A, Hildingsson I. The meaning of a very positive birth experience: focus groups discussions with woman. BMC Prenancy and Childbirth. 2015; 15(251): 1-8.

26. Etheridge J, Slade P. 'Nothing's actually happened to me.' ': the experiences of fathers who found childbirth traumatic BMC Pregnancy and Childbirth. 2017; 17(80): 1-15.

27. Bilgin NÇ, Ak B, Potur DC, Ayhan F. Doğum yapan kadınların doğumdan memnuniyeti ve etkileyen faktörler. Sağlık Bilimleri Meslekler Dergisi. 2018; 5(3): 342-353.

28. Newland LA, Coyl DD., Chen HH. Fathering and Attachment in the USA and Taiwan: Contextual Predictors and Child Outcomes. Early Child Development and Care. 2010; 180(1): 173-191.

29. Serçekuş P, Okumuş H. Fears associated with childbirth among nulliparous women in Turkey. Midwifery. 2009; 25(2) : 155-162.

30. Türk Dil Kurumu. Travma. Erişim Tarihi: 30.08.2020. http://tdk.gov.tr/ https://sozluk.gov.tr/

31. Yalnız Dincel H, Etki Genç R. Travmatik doğumun önlenmesinde ebenin rolü. Life Sciences (NWSALS). 2019; 14(3): 64-73.

32. Reed R, Sharman R, Inglis C. Women's descriptions of childbirth trauma relating to care provider actions and interactions. BioMedical Central Pregnancy and Childbirth. 2017; 17(21): 210.

33. Furuta M, Sandall J, Cooper D, Bick D. The relationship between severe maternal morbidity and psychological health symptoms at 6-8 weeks postpartum: a prospective cohort study in one English maternity unit. BioMedikal Central Pregnancy Childbirth. 2014; 7(14): 133

34. Foley S, Crawley R, Wilkie S, Ayers S. The birth memories and recall questionnaire (BirthMARQ): Development and evaluation. BMC pregnancy and childbirt. 2014; 14(1): 211.

35. Ayers S, Jessop D, Pike A, Parfitt Y, Ford E. The role of adult attachment style, birth intervention and support in posttraumatic stres after childbirth:A prospective study. Journal of Affective Disorders. 2014; 155: 295-298.

36. Uçar T, Gölbaşı Z. Nedenleri ve sonuçlarıyla doğum korkusu. İnönü Üniversitesi Sağlık Bilimleri Dergisi. 2015; 4(2); 54-58.

37. Öner S, Koçaş F. Mersinde 18-49 yaş arası bir grup kadında sezaryen sıklığ 1 ve etkileyen faktörler. TAF Preventive Medicine Bulletin [serial online]. 2016; 15(5): 401-407.

38. Dencker A, Taft C, Bergqvist L, Lilja H, Berg M. Childbirth experience questionnaire (CEQ): development and evaluation of a multidimensional instrument. BioMedical Central Pregnancy and Childbirt. 2010; 10(81): 1-8.

39. Çakmak B, Arslan S, Nacar MC. Kadınların isteğe bağlı sezaryen konusundaki görüşleri. Fırat Tıp Dergisi. 2014; 19(3): 122-125.

40. Nilsson L, Thorsell T, Hertfeltwahn E, Ekström A. Factors influencing positive birth experiences of first-time mothers. Nursing Research and Practice, Article ID 349124. 2013; 6 pages.

41. Aydın N, Yıldız H. Travmatik doğum deneyiminin etkileri ve nesiller arası aktarımı. Journal of Human Sciences. 2018; 15(1): 604-618.

42. Kocabaşoğlu N, Çorapçığlu Özdemir A, Yargıç İ, Geyran P. Türkçe "PTSD checklist - civilian version" (PCL-C) ölçeğinin geçerliliği ve güvenirliği. Yeni Sempozyum Dergisi. 2005; 43(3): 126-134.

43. Bay F. (2019). Kadınlarda travmatik doğum algısı ve postpartum depresyon ile ilişkisi. Yüksek Lisans Tezi, Eskişehir Osmangazi Üniversitesi, Eskişehir.

44. Grekin R, O'Hara M.W. Prevalance and risk factors of postpartum posttravmatic stres disorder: A meta-analsis. Clinical Psychology Review. 2014; 34(5): 389-401.

45. Greenfield M, Jomeen J, Glover L. What is traumatic birth? A concept analysis and literature review. British Journal of Midwifery Journal. 2016; 24(4): 254-267.

46. Aktaş S, Pasinlioğlu T. Ebelere verilen empati eğitiminin postpartum dönemdeki annelerin beklentilerini karşılama, doğumu ve ebeyi algılama düzeyine etkisi. Jinekoloji-Obstetrik ve Neonatoloji Tip Dergisi. 2017; 14(2): 60-65.

47. İşbir Gökçe G, İnci F. Travmatik doğum ve hemşirelik yaklaşımları. KASHE. 2014; 1(1): 29-40.

48. Condon JT, Corkindalea C, Boyce P. Assessment of postnatal paternal-infant attachment: Development of a questionnaire instrument. Journal of Reproductive and Infant Psychology. 2008; 26(3): 195-210. 